\title{
COST-EFFECTIVENESS OF NEEDLE AND CATHETER OVER NEEDLE WITH ACTIVE PROTECTION DEVICES IN THE HOSPITAL SETTING
}

\author{
Rodrigo Nonato Coelho Mendes ${ }^{1}$, Larissa Gutierrez de Carvalho Silva², Maria do Carmo Lourenço Haddad ${ }^{3}$, \\ Fernanda Novaes Moreno ${ }^{4}$, Roseli Broggi Gil ${ }^{5}$
}

\begin{abstract}
${ }^{1}$ Doctoral student in Sciences, Programa de Enfermagem Fundamental, Escola de Enfermagem de Ribeirão Preto (EERP), Universidade de São Paulo (USP). Specialist in Residency program in Nursing Service Management. Londrina, Paraná, Brazil. E-mail: rodrigo. coelho.mendes@gmail.com

${ }^{2}$ Doctoral student in Sciences, Programa de Enfermagem Fundamental, EERP/USP. Professor at Departamento de Enfermagem, Universidade Estadual de Londrina (UEL). Londrina, Paraná, Brazil. E-mail: larissagutierrez@yahoo.com.br

${ }^{3}$ Ph.D. in Fundamental Nursing. Professor at Departamento de Enfermagem da UEL. Londrina, Paraná, Brazil. E-mail: carmohaddad@gmail.com

${ }^{4}$ M.Sc. in Nursing. Nursing Manager at Hospital Evangélico de Londrina. Londrina, Paraná, Brazil. E-mail: fernanda.moreno@ helondrina.org.br

${ }^{5}$ M.Sc. in Sciences. Nurse at Hospital Universitário da UEL. Londrina, Paraná, Brazil. E-mail: roseligil@gmail.com
\end{abstract}

\begin{abstract}
The aim of this study was to evaluate the cost-effectiveness of needle and catheter over needle with active protection safety devices in the hospital context. A cross-sectional and retrospective study was undertaken at a public university hospital in Southern Brazil. The population was composed of consumption and material cost worksheets and 53 records of workers and students who suffered perforating accidents that occurred before and after the implementation of the safety devices, in the periods named A: June/2010 till June/2011 and B: June/2012 till June/2013. Data were analyzed using descriptive statistics. There was a 30\% increase in accidents between period A and period B. The cost went from 44.769,93 to 139.558,08 American dollars. Educational strategies are recommended to enhance the cost-effectiveness of safety devices in healthcare organizations.
\end{abstract}

DESCRIPTORS: Nursing. Occupational health. Hospital costs. Occupational acidents. Biological contamination.

\section{CUSTO-EFETIVIDADE DE AGULHAS E CATETERES SOBRE AGULHA COM DISPOSITIVOS DE PROTEÇÃO ATIVA NO CONTEXTO HOSPITALAR}

\begin{abstract}
RESUMO: Este estudo buscou avaliar o custo-efetividade de agulhas e cateteres sobre agulha com dispositivo de segurança de proteção ativa no contexto hospitalar. O estudo, que se caracteriza como pesquisa quantitativa, transversal e retrospectiva, foi realizado em um hospital universitário público do sul do Brasil. A amostra foi composta por planilhas de consumo e custo e 53 prontuários de trabalhadores e estudantes que sofreram acidentes com agulhas e cateteres sobre agulha, antes e após a implantação dos dispositivos de segurança, nos períodos denominados A: junho/2010 a junho/2011; e B: junho/2012 a junho/2013. Os dados foram analisados por meio de estatística descritiva. O estudo constatou que, mesmo com o dispositivo, houve um aumento de $30 \%$ de acidentes. O custo passou de $44.769,93$ para 139.558,08 dólares americanos. Dessa forma, concluiu-se que os novos materiais não redundaram em melhor custo-efetividade. Estratégias educativas são recomendadas, para que se possa potencializar o custo-efetividade desses materiais, nas organizações de saúde. DESCRITORES: Enfermagem. Saúde do trabalhador. Custos hospitalares. Acidentes de trabalho. Contaminação biológica.
\end{abstract}

\section{COSTO-EFECTIVIDAD DE AGUJAS Y CATÉTERES CON RELACIÓN A LAS AGUJAS CON DISPOSITIVOS DE PROTECCIÓN ACTIVA EN EL CONTEXTO HOSPITALARIO}

\begin{abstract}
RESUMEN: El estudio buscó evaluar el costo-efectividad de agujas y de catéteres con relación a las agujas con dispositivos de seguridad con protección activa en el contexto hospitalario. Es una pesquisa cuantitativa, transversal y retrospectiva, realizada en un hospital universitario público del sur de Brasil. La población estaba compuesta por plantillas de consumo y de costo, y con 53 expedientes de trabajadores y alumnos que sufrieron accidentes perforantes, ocurridos antes y después de la implantación de los dispositivos, durante los periodos A: de junio/2010 a junio/2011 y B: de junio/2012 a junio/2013. Se analizaron los datos mediante estadística descriptiva. Los accidentes aumentaron el 30\% entre el periodo A y el B. El costo pasó de 44.769,93 para 139.558,08 dólares americanos. Así, no hubo más costo-efectividad, se recomienda que las organizaciones de la salud utilicen estrategias para potencializar el costo-efectividad de los dispositivos de seguridad.
\end{abstract}

DESCRIPTORES: Enfermería. Salud laboral. Costos de hospital. Accidentes de trabajo. Contaminación biológica. 


\section{INTRODUCTION}

Work has a social meaning related to the construction of identity and marks an important stage of human development. Nevertheless, occupational activities can cause risks for the workers. ${ }^{1-3}$

In a survey from the International Labour Office (ILO) of the European Union, it was estimated that, around the planet, about 2.34 million people die each year due to occupational accidents or related illnesses. This fact causes a negative impact on the nations' economic development, which represents a severe public health problem. ${ }^{4}$

In the health area, the professionals are significantly exposed to accidents involving biological material, as they may have contact with blood and organic fluids. These fluids may be infected by bacteria, fungi and viruses, turning into contamination vehicles. Possible accidents in this area include accidents caused by piercing and cutting material. $^{3,5}$

In view of this situation, prevention and control measures are needed to avoid accidents involving biological material, mainly piercing and cutting tools. Different countries have discussed and regulated actions aimed at reducing those accidents..$^{6-8}$ The United States, for example, have specific laws to prevent needlestick accidents since 2000, when the Needlestick Safety and Prevention Act was issued. ${ }^{8}$ Italy has also had regulations for the same period, and Canada since 2008..$^{6-7}$

In Brazil, aiming to prevent, protect and promote the health workers' health, the Ministry of Labor and Employment issued Regulatory Standard (RS) 32, approved in Decree n. 485 on November $11^{\text {th }} 2005$, which among other orientations instructed the health establishments to offer piercing and cutting material with safety devices, within an adaptation deadline of five months. ${ }^{9}$

According to RS n. 32, the safety device is an item integrated into a set that includes the piercing-cutting element and a technology capable of reducing the risk of accidents, no matter what mechanism is used to activate it. ${ }^{9}$ These devices can be classified in two types: active protection devices, addressed in this study, which depend on the user's activation and are the most common at institutions; and passive protection devices, which are automatically activated. ${ }^{6}$

One important expected outcome when piercing and cutting materials with safety devices are used is the reduced incidence of accidents for the health team that is active in direct patient care as well as for the professionals responsible for the final disposal of the residues. ${ }^{7}$ On the other hand, the publication of RS n. 32 caused modifications in the production system of the industrial chain, which directly influenced the increase in the value of new products the health institutions purchase. ${ }^{9}$

In view of the above, this research was guided by the following questions: "Are needles and catheters over needles with an active protection safety device more cost-effective than the previous devices without this technology?"; and "Has the incidence of accidents involving piercing and cutting devices justified the costs of these new materials?". Thus, the objective in this study was to assess the cost-effectiveness of needles and catheters over needles with active protection safety devices in the hospital context.

This study is expected to contribute for professionals and health organizations to remain constantly alert in terms of supervision and education of human resources in health, with a view to enhancing the use of needles and catheters over needles with active protection safety devices, so as to make the health professionals' lives safer in their work environments.

\section{METHOD}

In this quantitative, cross-sectional and retrospective study, cost-effectiveness analysis is used. The study was undertaken at a public tertiary teaching hospital in the South of Brazil. The institution is affiliated with the Unified Health System (SUS) and, at the time the study was developed, i.e. during the first two months of 2014, the hospital offered 313 beds and attended a monthly average of 12,400 cases when adding the Emergency and Outpatient cases.

The study sample consisted of consumption and cost worksheets of hypodermal needles and peripheral catheters on needles, which contained active protection safety devices, as well as 53 histories of workers and students who were victims of perforating accidents before and after the implementation of the safety devices.

The research included the histories that contained records of accidents caused by lumen needles and catheters over needles during the periods the researchers had established. Histories containing other types of accidents or events that 
happened beyond the selected deadline were excluded. Blades and needle catheters with safety devices had not been standardized yet at the institution by the end of this study and, therefore, accidents involving these devices were not included.

For the purpose of the study, in the category "students", undergraduate students were considered who used the institution as a practicum area: nursing, physiotherapy, pharmacy, dentistry and medicine; this category also contained medical residency and multiprofessional students. The periods established were named using the letters $A$ and $B$, that is, the period without and with safety devices, covering one year each. Period A went from June 2010 till June 2011, and period B from June 2012 till June 2013.

These periods were set because the use of needles and catheters over needles with active protection devices was only fully established at the institution in June 2012. Catheters over needles with active protection safety devices were already present at the institution since 2010, but their consumption was only consolidated in period B. until then, devices without and with protection were used at the same time. The research data were collected between October and December 2013.

Before the use of needles and catheters over needles with active protection safety devices was implemented, the hospital offered training to the professionals on how to use and handle them. This training, which happened punctually, in response to the inclusion of the materials, was offered by the manufacturers as the products were being purchased. After that period, no records of additional training were found.

Cost-effectiveness is a measure used to indicate the most efficient alternative among different materials or interventions, so that the option that presents the best cost-effectiveness result is chosen, that is, the option that evidences the best or at least a satisfactory performance at the lowest price. This survey is a calculation in which the costs are confronted with the positive outcomes, always expressed in terms of gains, such as days of life, days without symptoms, among others. ${ }^{10}$

In this research, the factor Days without accidents was adopted as the positive outcome, and the cost-effectiveness was calculated by dividing the direct material cost by the number of Days without accidents involving needles and catheters over needles during the selected periods. This formula, demonstrated in Figure1, was applied to period A (without safety device) and to period B (with safety device).

$$
\text { Cost-effectiveness }=\frac{\text { Direct cost }}{\text { day without accident }}
$$

Figure 1 - Formula used to calculate the costeffectiveness. Brazil, 2014

The material cost was determined based on the mean price variation in the period and, for the calculation, only the direct purchasing cost of the items was considered, multiplying the individual values by the corresponding consumption. To calculate the days without accidents, a year of 365 days was considered and, from this value, the number of days when accidents happened was subtracted.

It is emphasized that the criterion the researchers established for the calculation did not take into account the number of accidents, but the number of days without accident events. This means that, even when more than one accident happened on a certain date, these events were accounted for as a single Day with accident.

The direct costs refer to goods, services and other resources consumed in care.${ }^{11}$ Hence, it are the amounts spent on the execution of the purchase of materials or the hiring of workforce. ${ }^{12}$ The indirect cost, on the other hand, requires an assessment process, as individual measuring is impossible, since it includes: physical structure, electrical energy, water, electricity, depreciation. ${ }^{12-13}$

In the research, the costs were calculated using the Brazilian currency, the real, which was converted into US dollars. Therefore, the on-line currency converter of the Brazilian Central Bank was used, on August 22 ${ }^{\text {nd }} 2014$, when one dollar (USD 1.00) was equivalent to $R \$ 2.2778$. The data were processed in Microsoft Office Excel and analyzed through descriptive statistics. Approval for the study was obtained from the Institutional Review Board of a Public State University, with CAAE 03997212.8.0000.5231, on July $10^{\text {th }} 2012$.

\section{RESULTS}

During the periods analyzed (June/2010June/2011; June/2012-June/2013), 53 accidents 
caused by lumen needles and catheters over needles happened at the place of study. Most of the accidents involved women $(68 \%, \mathrm{~N}=36)$, between 25 and 30 years of age $(42 \%, \mathrm{~N}=22)$ and students $(55 \%, \mathrm{~N}=29)$.
As can be observed in Table 1 , the cost of the day without accidents became $216.36 \%$ higher as a result of the use of new material - due to the increase in the number of accidents - so that the presence of the active protection device was not cost-effective.

Table 1 - Comparison of cost-effectiveness between needles and catheters over conventional needles and with an active protection safety device. Brazil, 2014

\begin{tabular}{lccc}
\hline \multicolumn{1}{c}{ Material } & Cost (USD) & $\begin{array}{c}\text { Effectiveness* } \\
\text { (days without accidents) }\end{array}$ & Relation cost-effectiveness \\
\hline Conventional & $44,769.93$ & 342 & USD 130.90/day without accidents \\
With device & $139,558.08$ & 337 & USD 414.12/ day without accidents \\
\hline${ }^{*}$ Considering year &
\end{tabular}

${ }^{*}$ Considering a year of 365 days.

It can also be observed that there was almost the number of days without accidents in the two periods, against expectations - more days without accidents. Among the 53 accidents caused by lumen/light needles and catheters over needles, which occurred in periods A and B, 23 happened in period $\mathrm{A}$ (without the device) and 30 in period $B$ (with device). Hence, the accidents increased, despite the use of material with active protection safety devices.
It was observed that the insertion of new materials (needles and catheters over needles with safety devices) did not result in a reduction in the number of accidents. In period $B$, when the devices were already used, a larger number of accidents was identified $(\mathrm{N}=30)$ than in period $\mathrm{A}$ $(\mathrm{N}=23)$, when that technology was not available. As regards the cost of these materials, an increase by $211.72 \%$ was observed in period B, as demonstrated in Table 2.

Table 2 - Cost analysis of needled materials in periods A and B. Brazil, 2014

\begin{tabular}{|c|c|c|c|c|c|c|c|c|}
\hline \multirow{2}{*}{ Item } & \multicolumn{4}{|c|}{ Period A* } & \multicolumn{4}{|c|}{ Period B† } \\
\hline & Cost $\ddagger$ & $\%$ & Mean & Deviation & Cost & $\%$ & Mean & Deviation \\
\hline Needles & $19,109.95$ & 42.7 & $1,469.99$ & \pm 126.36 & $104,313.11$ & 74.7 & $8,002.12$ & \pm 419.11 \\
\hline CON§ & $25,659.98$ & 57.3 & $1,973.84$ & \pm 240.46 & $35,244.93$ & 25.3 & $2,711.15$ & $\pm 1,752.53$ \\
\hline Total & $44,769.93$ & 100 & $3,443.84$ & \pm 366.82 & $139,558.08$ & 100 & $10,713.27$ & $\pm 2,171.64$ \\
\hline
\end{tabular}

*Period A: 06/2010 till 06/2011; †Period B: 06/2012 till 06/2013; † Purchase cost in American dollars; §CON: Catheters over needles.

In a more detailed analysis, it was observed that the amount spent on needles increased $445.9 \%$, and on catheters over needles $37.35 \%$. It could also be perceived that the mean spending per month on needles and catheters over needles corresponded to USD 3,443.84 in period A, against USD 10,713.27 in period B. Hence, the spending increased by $211.08 \%$ between the two periods.
In addition, in period $A$, most of the amount directed at the purchase of both material groups was focused on the acquisition of catheters over needles $(57.3 \%)$. In period B, however, the picture changed, as spending on needles became higher $(74.7 \%)$.

As the costs were calculated based on consumption, the latter needed to be analyzed, as demonstrated in Table 3. 
Table 3 - Analysis of needle and needle over catheter consumption in periods A and B. Brazil, 2014

\begin{tabular}{lcccccccc}
\hline \multirow{2}{*}{ Item } & \multicolumn{4}{c}{ Period A* } & \multicolumn{5}{c}{ Period B } \\
\cline { 2 - 9 } & Quantity & $\%$ & Mean & Deviation & Quantity & $\%$ & Mean & Deviation \\
\hline Needles & $1,088,216$ & 93.7 & 83,708 & \pm 7.196 & 824,738 & 92.7 & 72,210 & \pm 5.331 \\
CON $\ddagger$ & 73,148 & 6.3 & 5,627 & \pm 686 & 64,632 & 7.3 & 4,972 & \pm 606 \\
Total & $1,161,364$ & 100 & 89,336 & \pm 7.882 & 889,370 & 100 & 77,182 & \pm 5.937 \\
\hline *Period A: 06/2010 till 06/2011;† Period B: 06/2012 till 06/2013; $\neq$ CON: Catheters over needles.
\end{tabular}

As can be observed in Table 3, the consumption of needles and catheters over needles in period B dropped by $23.42 \%$ in relation to the previous period, despite the increase in the purchasing costs. It should also be clarified that, in period B as well, needles with and without the safety device were consumed at the same time. This consumption was dropping between June and October 2012, as can be observed in Table 4.

Table 4 - Percentage of needles with and without safety device in period B. Brazil, 2014

\begin{tabular}{lcccccr}
\hline & \multicolumn{7}{c}{ Period B* } \\
\cline { 2 - 7 } Month & $\mathbf{0 6 / 2 0 1 2}$ & $\mathbf{0 7 / 2 0 1 2}$ & $\mathbf{0 8 / 2 0 1 2}$ & $\mathbf{0 9 / 2 0 1 2}$ & $\mathbf{1 0 / 2 0 1 2}$ & $\mathbf{1 1 / 2 0 1 2}$ \\
\hline WD† & $70 \%$ & $80 \%$ & $96 \%$ & $95 \%$ & $99 \%$ & $100 \%$ \\
ND & $30 \%$ & $20 \%$ & $4 \%$ & $5 \%$ & $1 \%$ & - \\
Total & $100 \%$ & $100 \%$ & $100 \%$ & $100 \%$ & $100 \%$ & $100 \%$ \\
\hline
\end{tabular}

*Period B: June 2012 till June 2013; †WD: Needles with active protection safety device; $¥ N D$ : Conventional needles - no device

After October 2012, only needles with active protection devices were consumed in the organization. All catheters over needles consumed already had the active protection device since the start of period B, i.e. June 2012. In addition, a factor that may have interfered in this result was the increase in the consumption of Peripherally Inserted Central Catheters (PICC), which started being used at the institution in 2006. The consumption of this material increased approximately $34.73 \%$ in period $\mathrm{B}$ when compared to period A.

\section{DISCUSSION}

The results of this study showed that the presence of the active protection safety device was not cost-effective, as it did not result in the reduction of accidents involving needles and catheters over needles. In addition, the safety device lead to an increase by more than $400 \%$ in spending on needles and more than $30 \%$ in spending on catheters over needles. Nevertheless, the number of accidents at the institution in the same period increased and there were less days without accidents.
Both the cost and the cost-effectiveness analysis are important themes for nursing, as the area has increasingly added knowledge from the field of economics, as the nurses are included in decision processes on product purchases and sales. Thus, these professionals are active in financialinstitutional decisions and play their role as overseers of possible risks and of the quality of the products used, through the monitoring of the materials purchased and used in care. ${ }^{12,14}$

To remain active, nursing needs to strengthen its professional practice based on evidence and proof, based on the fact that making a decision on whether to use a technology should involve different aspects - legal, social, ethical, political, cultural and economic. As spending in the health sector has been increasing at an overwhelming rhythm, which can affect the sustainability of health organizations and systems, the implementation of constant care assessment and monitoring strategies is fundamental. ${ }^{10}$

In addition, although the financial management of a hospital is a very complex task, the Brazilian standard was elaborated without incen- 
tives and partnerships to mitigate the impact on costs, which often hampers the implementation of equipment with safety devices.

Studies demonstrate that needle pricks have been identified as the main caused of occupational accidents involving biological material. In this research, the predominance of female professionals among the accident victims has been identified, which is justified by the fact that most workers at health organizations are women. As found in other studies, this research identified individuals between 20 and 49 years as the most frequent accident victims. ${ }^{15-17}$

It is further highlighted that the nursing professionals are generally considered to be the most susceptible to accidents involving biological material, due to their constant contact with patients and their large number when compared to other categories of professionals in health institutions. ${ }^{17-20}$ Therefore, the use of active protection devices is related to the nursing professionals' adherence to the recommended standards.

In Brazil, research appoints that nursing technicians and auxiliary nurses are the most exposed to risk situations. In this research, however, the undergraduate and residency students were the most affected, which can be due to the fact that the institution is a teaching hospital. ${ }^{16}$

In a Canadian study, the authors identified that the workers' non-activation of the active protection device, in combination with the concomitant use of materials without safety devices, maintained the occurrence of needlestick accidents, despite the use of the safety device. ${ }^{7}$ It is highlighted that the safety activation was not assessed in this research.

On the other hand, an American study that followed 85 hospitals in ten American states showed that, after the law implemented in 2000, this type of accident dropped by $38 \% .{ }^{8}$ Another study refers that, when correctly activated, the active protection safety devices reduces the risk of accidents from $49 \%$ till $93 \%$.

Efforts are required to protect individuals exposed to risks. RS n. 32, for example, is a Brazilian standard that aims to protect health professionals and is based on three axes: continuing training of the workers; programs that address the risks; and protection measures against occupational risks. The latter axis includes the use of safety devices on needles and other piercing and cutting devices. ${ }^{9}$
The protection of workers to use needles and catheters over needles can be devised based on a structure that rests on these three axes of RS n. 32. The inexistence of one of these axes only ends up not offering support, so that the protection becomes inefficient. Due to the lack of ongoing training and risk prevention programs, needlestick accidents continue to happen, despite the available technology which, the more modern, tends to be more expensive.

In that context, the challenge that emerges is the promotion of long-lasting changes in the behavior of people working at health institutions, in view of these professionals' perceived resistance to develop new conducts. Continuing Education strategies are fundamental for that purpose. ${ }^{13,21}$

The method used was appropriate to achieve the research objective, but its main limitation was the incorrect completion of the records in patient histories. Hence, only the histories that explicitly contained the accident cause were included in the data collection, which led to a decrease in the study population.

\section{CONCLUSION}

At the end of the research, it was verified that the needles and catheters over needles with active protection safety devices were not cost-effective. The day without accident, which was the positive outcome adopted, started to demand a higher cost. Although more efficient technology was available, accident events increased due to the lack of ongoing research.

It can be inferred that the mere presence of the device does not guarantee the protection of the workers and students who develop their professional competences, demanding constant supervision. One alternative can be the purchase of materials with automated passive protection safety devices.

Based on the evidence, the organizations and professionals are alert to constant surveillance, no matter the type of protection adopted, making better use of the related cost. In addition, the quality of the accident notifications involving piercing and cutting material need to be assessed, so that the surveillance services can recognize, register, assess and intervene in this kind of problem.

The theme address can also inspire further research, such as studies on the users' activation of 
active protection safety devices or to understand the phenomena involved in the usage process of the safety devices. Studies involving blades and needled catheters can also be conducted in organizations where the use of these materials was already adapted to the standards.

\section{REFERENCES}

1. Pimenta AA, Freitas FCT de, Mendes AM de OC, Navarro VL, Robazzi ML do CC. Acidentes de trabalho ocorridos entre adolescentes. Texto Contexto Enferm [online]. 2013 [cited 2013 Sep 21]; 22(2):279-84. Available from http:/ / www.scielo.br/ pdf/tce/v22n2/v22n2a02.pdf

2. Flach L, Grisci CLI, Silva FM, Manfredini V. Sofrimento psíquico no trabalho contemporâneo: analisando uma revista de negócios. Psicol Soc [online]. 2009 [cited 2013 Sep 21]; 21(2):193-202. Available from http://www.scielo.br/pdf/psoc/ v21n2/v21n2a06

3. Souza RT, Bica CG, Mondadori CS, Ranzi AD. Avaliação de acidentes de trabalho com materiais biológicos em médicos residentes, acadêmicos e estagiários de um hospital-escola de Porto Alegre. Rev Bras Educ Med [online]. 2012 [cited 2013 Sep 21];36(1):118-24. Available from http:/ / www.scielo. $\mathrm{br} / \mathrm{pdf} / \mathrm{rbem} / \mathrm{v} 36 \mathrm{n} 1 / \mathrm{a} 16 \mathrm{v} 36 \mathrm{n1}$.pdf

4. International Labor Organization (ILO). Safety and Health at Work: Hopes and challenges in development cooperation. The example of an EUILO joint project "Improving safety and health at work through a Decent Work Agenda" [online]. 2013 [cited 2013 Sep 21]. Available from http://www. ilo.org/wcmsp5/groups/public/---ed_protect/--protrav/---safework/documents/publication/ wcms_215307.pdf

5. Rossin IR, Machado AA, Junqueira EM, Martinez R. Quantification of HIV-1 viral RNA in the blood in needles used for venous puncture in HIV-infected individuals. Rev Soc Bras Med Trop [online]. 2011 [cited 2013 Sep 21]; 44(6):661-4. Available from http://www.scielo.br/pdf/rsbmt/v44n6/02.pdf

6. Sossai D, Puro V, Chiappatoli L, Dagnino G, Odone B, Polimeri A, et al. Using an intravenous catheter system to prevent needlestick injury. Nurs Stand [online]. 2010 [cited 2013 Sep 21]; 24(29):42-6. Available from http:/ / rcnpublishing.com/doi/ pdfplus/10.7748/ns2010.03.24.29.42.c7628

7. Stringer BGA, Haines T, Kamsteeg K, Danyluk Q, Tang T, Kaboli F, et al. Conventional and sharp safety devices in 6 hospitals in British Columbia, Canada. Am J Infect Control [online]. 2011 [cited 2013 Sep 21]; 39(9):738-45. Available from http:/ / www. ajicjournal.org/article/S0196-6553(11)00105-2/pdf

8. Phillips EK, Conaway MR, Jagger JC. Percutaneous injuries before and after the Needlestick Safety and
Prevention Act. N Engl J Med [online]. 2012 [cited 2013 Sep 21]; 366(7):670-1. Available from http:// www.nejm.org/doi/pdf/10.1056/NEJMc1110979

9. Ministério do Trabalho e Emprego (BR). Portaria $n^{\circ} 485$, de 11 de novembro de 2005. Aprova a norma regulamentadora $n^{\circ} 32$ (Segurança e saúde no trabalho em estabelecimentos de saúde) [online]. 2005 [cited 2013 Sep 21]. Available from: http://www.mte.gov.br/legislacao/normas_ regulamentadoras/nr_32.pdf

10. Secoli SR, Nita ME, Ono-nita SK, Nobre M. Avaliação de tecnologia em saúde: II. A análise de custo-efetividade. Arq Gastroenterol [online]. 2010 [cited 2013 Sep 21]; 47(4):329-33. Available from http:/ / www.scielo.br/pdf/ag/v47n4/v47n4a02. pdf

11. Pinto M, Uga MAD. Os custos de doenças tabacorelacionadas para o Sistema Único de Saúde. Cad Saúde Pública [online]. 2010 [cited 2013 Sep 21]; 26(6):1234-45. Available from http://www.scielo. $\mathrm{br} / \mathrm{pdf} / \mathrm{csp} / \mathrm{v} 26 \mathrm{n} 6 / 16 . \mathrm{pdf}$

12. Castilho V, Lima AFC, Fugulin FMT, Peres HHC, Gaidzinski RR. Custo total com pessoal para implementação de um sistema de apoio à decisão em enfermagem. Rev Latino-Am Enferm [online]. 2014 [cited 2013 Sep 21]; 22(1):158-64. Available from http:/ / www.scielo.br/pdf/rlae/v22n1/pt_01041169-rlae-22-01-00158.pdf

13. Costa DB, Vannuchi MTO, Haddad MCFL, Cardoso MGP, Silva LG, Garcia SD. Custo de educação continuada para equipe de enfermagem de um hospital universitário público. Rev Eletr Enferm [online]. 2012 [cited 2013 Sep 21]; 14(2):257-66. Available from: http://dx.doi.org/10.5216/ree. v14i2.14540

14. Butsashvili M, Kamkamidze G, Kajaia M, Morse DL, Triner W, DeHovitz J, et al. Occupational exposure to body fluids among health care workers in Georgia. Occup Med [online]. 2012 [cited 2013 Sep 21]; 62(8):620-6. Available from http:// occmed.oxfordjournals.org/content/62/8/620. DOI:10.1093/occmed/kqs121

15. Lubenow JAM, Moura MEB, Nunes BMVT, Figueiredo MLF, Sales LC. Representações sociais dos acidentes com materiais perfurocortantes. Rev Latino-Am Enferm [online]. 2012 [cited 2013 Sep 21]; 20(6):1176-85. Available from http://www.scielo. br/pdf/rlae/v20n6/pt_21.pdf

16. Martins MDS, Silva NAP, Correia TIG. Acidentes de trabalho e suas repercussões num hospital ao Norte de Portugal. Rev Latino-Am Enferm [online]. 2012 [cited 2013 Sep 21]; 20(2):217-25. Available from http://www.scielo.br/pdf/rlae/v20n2/pt_02.pdf

17. Marziale MHP, Rocha FLR, Robazzi MLCC, Cenzi CM, Santos HEC, Trovó MEM. Influência organizacional na ocorrência de acidentes de trabalho com exposição a material biológico. Rev 
Latino-Am Enferm [online]. 2013 [cited 2014 Jan 21] 21(spe):199-206. Available from http:/ / www.scielo. br/pdf/rlae/v21nspe/pt_25.pdf

18. Silva TR, Rocha AS, Ayres JA, Juliani CMCM. Acidente com material perfurocortante entre profissionais de enfermagem de um hospital universitário. Rev Gaúch Enferm [online]. 2010 [cited 2013 Sep 21]; 31(4):615-22. Available from http:// www.scielo.br/pdf/rgenf/v31n4/a02v31n4.pdf

19. Vieira M, Padilha MI, Pinheiro RDC. Análise dos acidentes com material biológico em trabalhadores da saúde. Rev Latino-Am Enferm [online]. 2011 [cited 2013 Sep 21]; 19(2):332-9. Available from http://www.scielo.br/pdf/rlae/v19n2/pt_15.pdf
20. Soto-Fuentes P, Reynaldos-Grandón K, MartínezSantana D, Jerez-Yáñez O. Competencias para la enfermera/o en elámbito de gestión y administración: desafíos actuales de la profesión. Aquichan [online]. 2014 [cited 2014 Apr 21]. Available from http:// aquichan.unisabana.edu.co/index.php/aquichan/ article/view/2684

21. Barbosa GC, Meneguim S, Lima SAM, Moreno V. Política Nacional de Humanização e formação dos profissionais de saúde: revisão integrativa. Rev Bras Enferm [online]. 2013 [cited 2013 Sep 21]; 66(1):123-7. Available from http://www.scielo.br/pdf/reben/ v66n1/v66n1a19.pdf 